\title{
Hegemoni Ideologi dalam Novel Ketika Cinta Bertasbih Karya Habiburrahman el Shirazy (Kajian Hegemoni Gramsci)
}

\author{
Fajrul Falah \\ Fakultas Ilmu Budaya, Universitas Diponegoro \\ fajrulfalah.fib@live.undip.ac.id
}

\begin{abstract}
This research is background by the idea that novels are works that do not only highlight the aesthetic elements of language, but as a medium or means for authors to convey their mission and message. The novel is full of meaning, either clear or implied. Mission, motif, purpose of the author represented through the fictional characters he constructed. The purpose of the research is to reveal the form ideological hegemony in the novel Ketika Cinta Bertasbih (KCB) creation Habiburrahman el Shirazy. Research on novels $K C B$ with the Gramsci hegemony approach the author's knowledge is based search in online journals indexed doaj.org, in the last five years it has not been found. The research method used is descriptive qualitative. The research approach used Gramsci hegemony. The results of the research show, central figure in a novel like Khairul Azzam dan Anna Althafunnisa able to deal with life's problems well (happines), because they believe and carry out ther ideology anda religious values. The main problem thet emerged from the two figures was like education, romance, and marriage. The process of hegemony that occurs between two figures and most of the other characters went will, so that able to dampen potential conflict between character.
\end{abstract}

Keywords: Value, ideology, religion, author, and hegemony.

\section{Intisari}

Penelitian ini dilatarbelakangi pemikiran bahwa novel merupakan hasil karya yang tidak hanya menonjolkan unsur estetik bahasa, tetapi sebagai media atau sarana bagi pengarang untuk menyampaikan misi dan pesan. Novel sarat makna, baik yang tersurat maupun tersirat. Misi, motif, dan tujuan pengarang direpresentasikan melalui tokoh-tokoh fiksi yang dikontruksikannya. Tujuan penelitian ini untuk mengungkapkan bentuk hegemoni ideologi yang terdapat dalam novel Ketika Cinta Bertasbih (KCB) karya Habiburrahman el Shirazy. Penelitian terhadap novel $K C B$ dengan pendekatan hegemoni Gramsci, sepanjang yang penulis ketahui berdasarkan pencarian di jurnal online terindeks doaj.org, dalam lima tahun terakhir belum ditemukan. Metode penelitian yang digunakan adalah deskriptif kualitatif. Pendekatan penelitian yang digunakan adalah hegemoni Gramsci. Hasil penelitian menujukkan, tokoh-tokoh sentral dalam novel seperti Khairul Azzam dan Anna Althafunnisa mampu menghadapi persoalan hidup dengan baik (kebahagiaan) karena percaya dan menjalankan ideologi dan nilai-nilai keagamaan yang dianutnya. Persoalan utama yang muncul kedua tokoh tersebut seperti pendidikan, percintaan, dan 
pernikahan. Proses hegemoni yang terjadi di antara dua tokoh tersebut dan sebagian besar tokoh lainnya berjalan baik, sehingga mampu meredam potensi konflik antartokoh.

Kata Kunci: Nilai, ideologi, agama, pengarang, dan hegemoni.

\section{Pendahuluan}

Teks yang terdapat dalam karya sastra (baca: novel) mengandung makna baik secara tersirat maupun tersurat. Pengarang menciptakan novel dengan menggunakan bahasa (kosa-kata, frase, diksi, kalimat) tidaklah mandiri atau tidak kontekstual. Bahasa yang digunakan pengarang dan narasi yang diciptakan dalam novel bahkan diidentikkan dengan latar belakang penciptanya. Latar belakang pengarang tersebut di antaranya pendidikan, lingkungan (baik geografis maupun sosial), dan pandangan hidup (wolrdview). Dalam konteks ini, sekalipun novel adalah fiksi yang dikontruksikan sedemikian rupa, sarat muatan-muatan pesan dan bahkan ideologi pengarang. Jika demikian, terlepas ada unsur estetik gramatikal yang menarik dalam novel, maka pengarang memiliki peranan penting untuk menempatkan karyanya. Apakah karya (narasi dalam novel) tersebut, memiliki pesan baik kemudian mampu mempengaruhi dan membawa pembaca (publik) ke arah positif ataukah sebaliknya. Apakah bahasa dan pesan dalam novel tersebut dimaknai sebagai ayat-ayat Tuhan ataukah "ayat-ayat setan"? Salah satu novel yang diindikasikan penuh muatan pesan penciptanya dan bisa mempengaruhi pembaca adalah Ketika Cinta Bertasbih karya Habiburrahman el Shirazi.

Novel Ketika Cinta Bertasbih (KCB) merupakan karya yang diidentikkan dan cukup melekat pada Habiburrahman el Shirazy, selain Ayat-Ayat Cinta. Habiburrahman termasuk sastrawan Indonesia yang cukup produktif dan mendapatkan banyak penghargaan kesusastraan di antaranya pena award 2005 oleh Forum Lingkar Pena (FLP), tokoh perubahan Indonesia 2007 (Republika), dan IBF award 2006. Selain dua novel tersebut, karya-karya pengarang kelahiran Semarang itu di antaranya, Bidadari Bermata Benin, Bumi Cinta, Dalam Mihrab Cinta, Di Atas Sajadah Cinta, dan Pudarnya Pesona Cleopatra. Secara garis besar, sebagaimana diketahui karakteristik karya-karya Habiburrahman, novel-novel tersebut dan $K C B$ bertemakan tentang cinta baik kepada sesama maupun sang pencipta, dan dalam bingkai Islam. Di antara novel-novel tersebut, novel $K C B$ cukup fenomenal dan popular di kalangan pembaca dan penonton (mega 
bestseller), dibaca lebih dari lima juta orang (lihat Basmala, 2009). KCB diterbitkan oleh Basmala-Republika pada 2007, dua tahun berikutnya dilayarputihkan (film).

Tokoh-tokoh dalam novel $K C B$ sebagian besar diciptakan dengan karakteristik positif seperti baik hati, taat, penuh cinta kasih, tampan, cantik, dan cerdas. Tokoh sentral atau utama terdapat pada sosok Abdullah Khairul Azzam (Azzam) yang diindikasikan memiliki banyak kelebihan dan citra positif. Citra baik tersebut yang kemudian membuat tokoh-tokoh lain sebagian terpikat dan respek terhadap Azzam. Tokoh-tokoh dalam novel $K C B$ itu antara lain Anna Althafunnisa, Elliana, Ayatul Husna, Furqan Andi Hasan, Kyai Lutfi, dan Ilyas. Tokoh-tokoh tersebut mengarah dan berpusat pada sosok Azzam. Mengapa tokoh-tokoh lain terpengaruh dan sebagian besar mengagumi Azzam? Mengapa pula sebagian besar aktivitas Azzam menjadi panutan dan mendapatkan persetujuan dengan mudah, terutama pada tokoh-tokoh peremuan? Melalui sosok Azzam, diindikasikan terdapat muatan pesan positif yang ingin disampaikan pengarang. Pesan seperti apa yang ingin disampaikan pengarang melalui Azzam? Novel $K C B$ menarik untuk diteliti.

Terkait tinjauan pustaka, sepanjang yang penulis ketahui berdasarkan pencarian jurnal online yang terindeks doaj.org di internet (kata kunci: novel Ketika Cinta Bertasbih), belum ditemukan penelitian $K C B$ dari perspektif hegemoni Gramsci. Beberapa penelitian terkini yang terkait dengan $K C B$ dari perspektif lain dalam 5 tahun terakhir adalah (1) Efendi (2012) mengkaji $K C B$ menggunakan pendekatan strukturalisme-dinamik (semiotik). Fokus kajian ini mendeskripsikan realitas profetik dalam novel karya Habiburrahman el Shirazy tersebut. Hasil kajian menunjukkan, realitas profetik terdapat dalam aspek relasi antara laki-laki dengan perempuan dalam perspektif individual dan komunal (sosial). Realitas profetik juga terdapat dalam aspek transenden yang terkait kesadaran ketuhanan. Penelitian lain (2) Isnaniah (2015), meneliti novel $K C B$ ditranformasikan ke film. Fokus penelitian ini mentranformasi novel ke dalam film (ekranisasi). Hasil penelitian menunjukkan, terdapat perbedaan antara film dengan novel yang disebabkan oleh resepsi penulis skenario, sutradara, dan produser terhadap novel $K C B$.

Penelitian terkait juga telah dilakukan oleh (3) Mulyadi (2016) mengkaji $K C B$ dari aspek nilai moral. Fokus penelitian ini menggunakan metode analisis wacana dan menekankan nilai moral yang terdapat dalam novel tersebut. Hasil penelitian 
menunjukkan, bahwa novel $K C B$ sarat muatan moral yang bisa membentuk moral pembaca atau publik. Nilai moral yang terdapat novel tersebut seperti iman, sabar, optimis, dan tanggungjawab. Penelitian lain yang terkait hegemoni ideologi dan mengkaji karya Habiburrahman el Shirazy dilakukan oleh (4) Fajrul (2018). Fokus penelitian yang dilakukan oleh Fajrul pada aspek hegemoni dan ideologi dalam novel Ayat-Ayat Cinta dengan metode yang digunakan deskriptif analisis. Hasil riset menunjukkan tokoh Utama Fahri diciptakan pengarang dengan karakteristik yang positif seperti cerdas, taat, dan baik hati. Fahri menjadi kelas dominan dan menjalankan ideologi keagamaan. Penelitianpenelitian tersebut dikaji dari pendekatan masing-masing, penulis akan memfokuskan penelitian terhadap novel $K C B$ dari pendekatan hegemoni Gramsci. Tujuan penelitian in untuk mengungkapkan bentuk hegemoni ideologi yang direpresentasikan melalui tokohtokoh sentral yang terdapat dalam novel $K C B$.

Hegemoni merupakan bentuk kepemimpinan dan kekuasaan yang diperoleh melalui cara konsensus atau persetujuan, bukan keterpaksaan. Kekuasaan hegemoni didapat dengan cara yang damai, bukan kekerasan atau penindasan. Mekanisme kepemimpinan hegemoni dilakukan dengan cara politis dan ideologis (Lihat Gramsci, 1971:57; Simon, 2001:21; Fajrul, 2018: 353). Kekuasaan hegemoni tidak hanya terjadi pada skala besar antarnegara, melainkan juga bisa dimaknai ke ranah kecil, yakni individual atau personal. Individu atau kelas sosial tertentu menguasai individu atau kelompok lainnya melalui persetujuan dan ideologis. Ideologi (dalam karya sastra) merupakan gagasan, keyakinan, dan kesadaran yang dipercayai masyarakat sebagai panduan untuk menjalani aktivitas dan worldview mereka (Lihat Fajrul, 2017: 102). Ideologi dalam kepemimpinan hegemoni berjalan melalui lembaga-lembaga sosial, pendidikan, kaum atau tokoh intelektual. Ideologi memiliki peranan penting karena mampu mereduksi perlwanan pihak kontra mengikat kelas-kelas sosial yang antagonistik (Lihat Faruk, 2010, 135-136; Kurniawan, 2012: 74). Secara singkat, hegemoni ideologi yang diapikasikan untuk menganalisis novel $K C B$ dimaknai sebagai bentuk penerimaan dan persetujuan kelas sosial (subordinat) terhadap kekuasaan yang diperankan oleh kelas dominan yang direpresentasikan melalui tokoh-tokoh sentral yang terdapat dalam novel tersebut.

\section{Metode Penelitian}


Penelitian ini termasuk ranah penelitian kepustakaan dengan pengumpulan data melalui studi pustaka. Objek material penelitian ini ialah novel Ketika Cinta Bertasbih karya Habiburrahman el Shirazi. Objek formalnya adalah hegemoni ideologi yang terdapat dalam novel itu. Pendekatan yang digunakan dari ranah sosiologi sastra, yaitu hegemoni Gramsci. Metode yang digunakan untuk mengkaji novel $K C B$ adalah deskriptif analisis. Langkah kerja penelitian ini meliputi pengumpulan data, analisis, dan hasil analisis (penyajian). Pengumpulan data dilakukan dengan cara membaca secara cermat novel $K C B$ kemudian memilah dan memilih kutipan-kutipan atau teks yang relevan dengan ideologi dan hegemoni yang terdapat dalam novel. Kutipan yang terkait dengan kekausaan hegemoni melalui tokoh-tokoh dalam $K C B$ kemudian dipilih dan dianalisis dengan cara diinterpretasikan secara kritis. Hasil analisis tersebut lalu disajikan secara deskriptif kualitatif.

\section{Hasil Analisis}

Sebelum masuk ke analisis hegemoni ideologi, terlebih dahulu dipaparkan singkat posisi dan peran tokoh-tokoh yang terdapat dalam novel $K C B$ yang dianggap relevan untuk dianalisis. Sebagaimana umumnya novel Habiburrahman yang lain, yang menempatkan sosok laki-laki sebagai tokoh utama, pada novel $K C B$ pun demikian. Sosok laki-laki bernama lengkap Abdullah Khairul Azzam menjadi tokoh sentral dan pusat cerita. Azzam direpresentasikan sebagai tokoh yang memiliki banyak atribut positif seperti sederhana, pekerja keras, baik hati, tampan, cerdas, dan mandiri. Dengan citra positif tersebut, secara kelas sosial Azzam memiliki peran dominan dan kuasa terhadap tokoh-tokoh lainnya.

Tokoh-tokoh lain dalam $K C B$ ada Anna Althafunnisa, Ayatul Husna, Elliana, Furqan, Kyai Lutfi, Ustadz Mujab, dan Ilyas. Anna merupakan perempuan cantik, kaya, dan berakhlak baik. Ia anak Kyai Lutfi, pemilik pesantren di desa Wangen. Tokoh perempuan tersebut memiliki peran cukup signifikan karena diakhir cerita ia menikah dengan tokoh utama Azzam. Ada tokoh laki-laki yang ada dipusaran cinta dan pernikahan antara Anna dan Azzam, yakni Furqan. Laki-laki yang digambarkan kaya dan sedang menempuh studi S3 di Kairo itu, melamar Anna ditemani tokoh Ilyas. Furqan merupakan suami pertama Anna sebelum keduanya sepakat bercerai.Tokoh-tokoh tambahan lain dalam $K C B$ ada Elliana (gadis cantik lulusan Jerman yang jatuh cinta pada Azzam), dan Ayatul Husna (calon istri Azzam yang batal menikah), dan Ustadz Mujab 
(sahabat serta tokoh yang membantu Azzam melamar Anna). Selain tokoh utama Azzam, tokoh-tokoh tambahan tersebut secara analisis posisi dan hegemoni berada pada kelas subordinat (terhegemoni), meskipun demikian posisi mereka tidak statis, mereka juga bisa menjadi tokoh yang memiliki peran posisi kelas sosial dominan, tergantung sudut pandang dan konteks narasi dalam $K C B$.

\section{Ideologi Kegamaan}

Sebagian besar tokoh-tokoh dalam novel $K C B$ jika dimaknai, mereka memerankan dan menjalankan kehidupan agamanya. Novel tersebut bernuansa agama Islam, seperti karakteristik novel-novel karya Habiburrahman lainnya. Ideologi keagamaan dalam $K C B$ dimaknai sejauh mana kepercayaan, keyakinan, tokoh-tokoh tersebut terhadap nilai-nilai agama yang dianutnya. Nilai-nilai dan keyakinan tersebut oleh tokoh bahkan dijadikan landasan untuk bertindak dalam menghadapi tiap persoalan hidup. Sosok laki-laki yang taat menjalankan agamanya adalah Azzam. Ia rajin menjalankan shalat lima waktu dan berdoa. Tidak hanya berdoa, Azzam termasuk sosok pekerja keras. Azzam saat kuliah di Kairo, bahkan harus menghidupi ekonomi keluarganya dengan cara berjualan tempe. Konsekuensi logis yang diterima Azzam karena kuliah sambil bekerja adalah butuh waktu 9 tahun untuk lulus. Masa kuliah relatif lama tersebut, memunculkan pendapat "bukan kuliah sambil bekerja, tetapi bekerja sambil kuliah".

Kepercayaan dan implementasi Azzam pada nilai agama yang dianutnya salah satunya terletak pada keyakinanakan buah silaturahmi. Silaturahmi yang diyakini Azzam sebagai pintu rezeki inilah yang membuat ia bekerja berjualan tempe. Azzam belajar dan menekuni proses pembuatan tempe, saat ia silaturahmi ke rekannya bernama Handono di Salatiga, "Ia merasakan benar bahwa rezeki yang didatangkan oleh Allah dari silaturrahmi sangat dahsyat. Ia bisa sampai belajar sampai Al Azhar University juga bermula dari silaturahmi"'(KCB, 2009: 155). Kutipan tersebut menujukkan bahwa silaturahmi berbuah manis, hanya sebagian orang yang menyadari apa yang didapatkannya tidak lepas dari silaturahmi. Azzam bahkan bisa kuliah di universitas bereputasi di Mesir tersebut, informasi awalnya didapat saat silaturahmi dan menjenguk rekannya bernama Wasis di rumah sakit. Keberhasilan Azzam kuliah dan berjualan tempe tersebut, merupakan contoh berkat silaturahmi, "Agar siapa saja yang ingin diluaskan rezekinya, hendaklah ia melakukan silaturahmi ( $K C B$, 2009: 156). 


\section{Meminang Anna Althafunnisa}

Dalam novel $K C B$ potongan narasi yang dianggap menarik dan menjadi klimaks cerita adalah prosesi lamaran (khitbah) dan perkawinan (nikah). Hal itu terjadi saat tokoh sentral Azzam ingin meminang gadis cantik Anna Althafunnisa. Azzam yang memiliki karaktersitik positif, meminta izin dan bantun Ustadz Mujab yang tidak lain adalah sepupu Anna. Sekalipun Azzam sebagai tokoh utama, jika disandingkan dengan Ustadz Mujab, maka ia sebagai kelas subordinat (terhegemonik), sedangkan Ustadz Mujad sebagai kelas dominan (menghegemoni). Hal ini karena Azzam berharap dan Ustadz Mujab memiliki andil atau peran untuk mewujudkan harapan sosok laki-laki yang dikenal sederhana tersebut. Sebagian besar atau umumnya orang, apalagi teman dekat atau guru, jika dimintai bantuan maka dengan senang hati menuanaikan atau mewujudkannya. Akan tetapi, harapan Azzam untuk meminang dan menikahi Anna, tidak berbanding lurus dengan jawaban Ustadz Mujab. Secara halus Ustadz Mujab menolak Khairul Azzam dan memintanya untuk mencari prempuan lain. Selain, itu Anna akhirnya menjadikan Furqan sebagai pilihan pertamanya (suami).

Kalau ingin memperistri seperti dia, cobalah kau menstandarkan dirimu dulu seperti dia. Kalau aku jadi orang tuanya, dan ada dua mahasiswa Al Azhar yang satu serius belajarnya yang satu hanya sibuk membuat tempe. Maaf Rul, pasti aku akan memilih yang lebih serius belajamya. Kau tentu sudah paham maksudku. Bukan aku ingin menyinggungmu, tapi aku ingin kau memperbaiki dirimu (KCB, 2009: 70-71).

Kutipan di atas menunjukkan, pada satu sisi Ustadz Mujab ingin membantu Azzam segera menikah, menjalankan perintah agama yang dianutnya, sisi lain ia menggap Azzm belum pantas menjadi pendamping perempuan sekaliber Anna Althafunnisa. Mengapan jawaban Ustadz Mujab demikian? Dalam konsepsi ideologi yang diusung Ustadz Mujab bahwa jika seseorang ingin menikah, maka nikahilah orang yang sekufu' (selevel). Level atau indikator yang dipertimbangkan tidak hanya agama, keturunan, kecantikan, bahkan sampai ke ranah pendidikan serta strata sosial. Anna merupakan gadis berprestasi, kaya, dan keturunan orang terpandang, sementara Azzam adalah mahasiswa dari keluarga sederhana. Peryataan dan jawaban Ustadz Mujab memperjelas gap dan kesenjangan kelas antara Azzam dengan Anna. 
Kesenjangan kelas sosial (gap) semakin nampak dan bisa menimbulkan konflik antara Azzam dan sang ustadz. Secara tersirat Ustadz Mujab juga memunculkan memunculkan pandangan bahwa idealnya laki-laki di atas atau lebih tinggi dari perempuan, baik dari pendidikan maupun penghasilan (materi). Siapakah laki-laki yang tidak kecewa, manakala lamaran pernikahannya ditolak? Bahkan sebelum lamaran tersebut disampaikan kepada perempuan yang dicintainya. Siapa pula laki-laki yang tidak tersinggung atau marah ketika disinggung strata sosialnya lebih rendah dibandingkan strata sosial perempuan yang akan dipinang? Dialah sosok bernama lengkap Abdullah Khairul Azzam. Sekalipun kesenjangan sosial menggejala, namun kedua kelas sosial antara Azzam dan Ustadz Mujab dalam relasi yang baik. Hal ini terjadi karena hegemoni yang diikat oleh ideologi sekufu' tadi.

Azzam menerima pandangan dan nasihat sang ustad, bukan membantah atau melawannya. Azzam menerima kenyatan dan menyadari bahwa ia pemuda penjual tempe yang tidak kunjung selesai kuliah S1 di Universitas Al Azhar Kairo, Mesir. Kesadaran inilah yang kemudian menuntun dirinya untuk mulai berpikir tidak mendekati Anna Althafunnisa, "Allah belum mengijinkan aku menikah. Aku masih harus memperhatikan adik-adikku sampai ke gerbang masa depan yang jelas dan cerah. Kalau aku menikah saat ini, perhatianku pada adik-adikku akan berkurang" (KCB, 2009:73). Kesadaran dan fakta bahwa Azzam belum mampu meminang Anna, karena ia mempercayai ideologi agama yang dianutnya meyakini bahwa yang terjadi pada Azzam merupakan sudah takdir atau ketentuan Tuhan, sehingga diterima dengan baik. Azzam adalah sosok yang taat dan tanggungjawab, ia bahkan harus merelakan untuk menunda keinginan personalnya (meminang-menikah) demi tanggungjawab yang lebih besar yang sedang diemban, yakni menghidupi (ekonomi) kelaurganya.

Nilai-nilai kebaikan seperti tanggungjawab dan prinsip kuat yang melekat pada diri Azzam. Ideologi tanggungjawab (menafkahi) keluarga menunjukkan kediriannya sebagai common sense-nya sebagian masyarakat Jawa (Solo; keluarga Azzam tinggal). Dalam bahasa masyarakat Azzam, dijumpai pitutur atau nasihat "jika orang tua sudah meninggal, dan meninggalkan anak, maka anak (laki-laki) yang paling besar (Jawa: mbarep) yang menanggung nafkah keluarga”. Ideologi inilah kemudian membuat Azzam bekerja keras, baik dalam menuntut ilmu, maupun bekerja untuk mewujudkan cita-cita (lulus kuliah dan sukses berbisnis). Ideologi tersebut pulalah yang mampu mereduksi rasa 
kecewa dan menjadikan obat dari pahitnya menahan kesabaran untuk menikahi perempuan cantik putrid Kyai Lutfi. Sekalipun sabar prosesnya pahit, namun hasilnya manis. Berkat kerja keras, doa, dan kesabaran Azzamlah akhirnya ia ditakdirkan bisa menikahi perempuan pujaan hatinnya, Anna Althafunnisa.

\section{Simpulan}

Novel $K C B$ karya Habiburrahman tidak sekadar menonjolkan keindahan bahasa dalam teks cerita, melainkan juga penuh makna dan pesan pengarang. Narasi dan pesan yang terdapat dalam novel tersebut bahkan tidak lepas dari latar kehidupan sosial pengarangnya. Sekalipun novel itu fiksi, ada tokoh, latar, alur, yang dikonstruksikan sedemikan rupa terdapat kesamaan dengan pengalaman kehidupan pengarangnya. Salah satu kesamaan tersebut yang terdapat dalam $K C B$ adalah studi di Universitas Al Azhar, Kairo, Mesir. Melalui pengalaman hidup yang kemudian dinarasikan dalam bentuk novel, dalam $K C B$ sarat muatan ideologi keagamaan. Nilai-nilai ideologi keagamaan ini kemudian dijalankan dan diperankan oleh sebagian besar tokoh-tokoh untuk menghadapi persoalan hidup yang muncul (konflik). Tokoh-tokoh yang memiliki peran tersebut yang utama adalah Khairul Azzam dan Anna Althafunnisa. Persoalan hidup yang dominan muncul pada dua sosok tersebut adalah pendidikan dan percintaan (jodoh). Sekalipun persoalan cinta dan jodoh merupakan pokok pembahasan yang sensitif dan potensi memunculkan konflik, dalam novel $K C B$ tokoh-tokoh yang terlibat (Anna dan Azzam) dikemas dalam relasi yang baik. Novel $K C B$ bahkan didominasi tokoh-tokoh dengan karakter yang positif (protagonis) dan sarat ideologi keagamaan yang dianut para tokoh tersebut. Dengan karakter dan ideologi tokoh tersebut, potensi konflik yang muncul bisa diredam dan diatasi dengan baik (happy ending). Dalam konteks ini, melalui novel pengarang sebenarnya memberikan pilihan-pilihan sikap yang bisa memberikan contoh terkait bagaimana mengatasi persoalan hidup, terutama soal studi dan jodoh.

\section{Daftar Pustaka}

Efendi, Anwar. (2012). Realitas Profetik dalam Novel Ketika Cinta Bertasbih Karya Habiburrahman El-Shirazy. Jurnal Litera, Vol 1 No. 1. Hal. 72-82. Diaksesmelalui https://journal.uny.ac.id/index.php/litera/article/view/1148, pada Selasa 20/11/2018 pukul 20.09 WIB. 
El Shirazy, Habiburrahman. 2009. Ketika Cinta Bertasbih. Jakarta : Basmala.

Falah, Fajrul. 2017. Ideologi dan Kelas Sosial Pengarang dalam Novel Matinya Sang Penguasa Karya Nawal el Sadawi: Kajian Sastra Marxis. Jurnal USA,Vol.12.No.2 hal.100-107.Diakses melalui http:iiejournal.undip.ac.id/index.php/nusa/article/view/15676/11371, pada 27/11/2018 pukul 06.10 WIB.

. 2018. Hegemoni Ideologi dalam Novel Ayat-Ayat Cinta Karya Habiburrahman el Shirazy (Kajian Hegemoni Gramsci). Jurnal NUSA, Vol. 13, No.3, hal. 351360.Diakses melalui https://ejournal.undip.ac.id/index.php/nusa/article/view/20497/13909, pada 23/11/2018 pukul 21.20 WIB.

Faruk. 2010. Pengantar Sosiologi Sastra dari Strukturalisme Genetik sampai PostModernisme. Yogyakarta: Pustaka Pelajar.

Gramsci, Antonio. 1971. Selections from Prison Notebook, edited and translated by Quentin Hoare and Geoffray N Smith, London: Lawrenceadn Wishart.

Isnaniah, Siti. 2015. Ketika Cinta Bertasbih Transformasi Novel ke Film. Jurnal Kawistara, Vol. 5, No. 1, hal. 23-35. Diakses melalui https://jurnal.ugm.ac.id/kawistara/article/view/6401, pada Senin 19/11/2018 pukul 22.05 WIB.

Kurniawan, Heru. 2012. Sosiologi Sastra: Teori, Metode, dan Aplikasi. Yogyakarta: Graha Ilmu.

Mulyadi. 2016. The Values of Moral Learning in "Ketika Cinta Bertasbih" Novel Written by Habiburrahman El Shirazy. Jurnal Al Ta'lim Vo.3 No. 2, hal. 156-168. Diakses melalui http://journal.tarbiyahiainib.ac.id/index.php/attalim, pada Rabu 21/11/2018 pukul 21.05 WIB.

Simon, Roger. 2001. Gagasan-gagasan Politik Gramsci. Terj. Kamdani dan Imam baihaqi. Yogyakarta: Pustaka Pelajar. 